\title{
Methodology of Researching Teenage Literary Self-Educational Courses
}

\author{
Author: Kamil Rafikov \\ ORCID: 0000-0002-7828-2488 \\ Email: mailbox@kamil-rafik.com \\ This document is distributed under CC BY 4.0 license. \\ DOI: 10.5281 /zenodo.4028474 \\ Updated at September 14 $4^{\text {th }}, 2021$. \\ Edition: 19.
}

\section{Table of Contents}

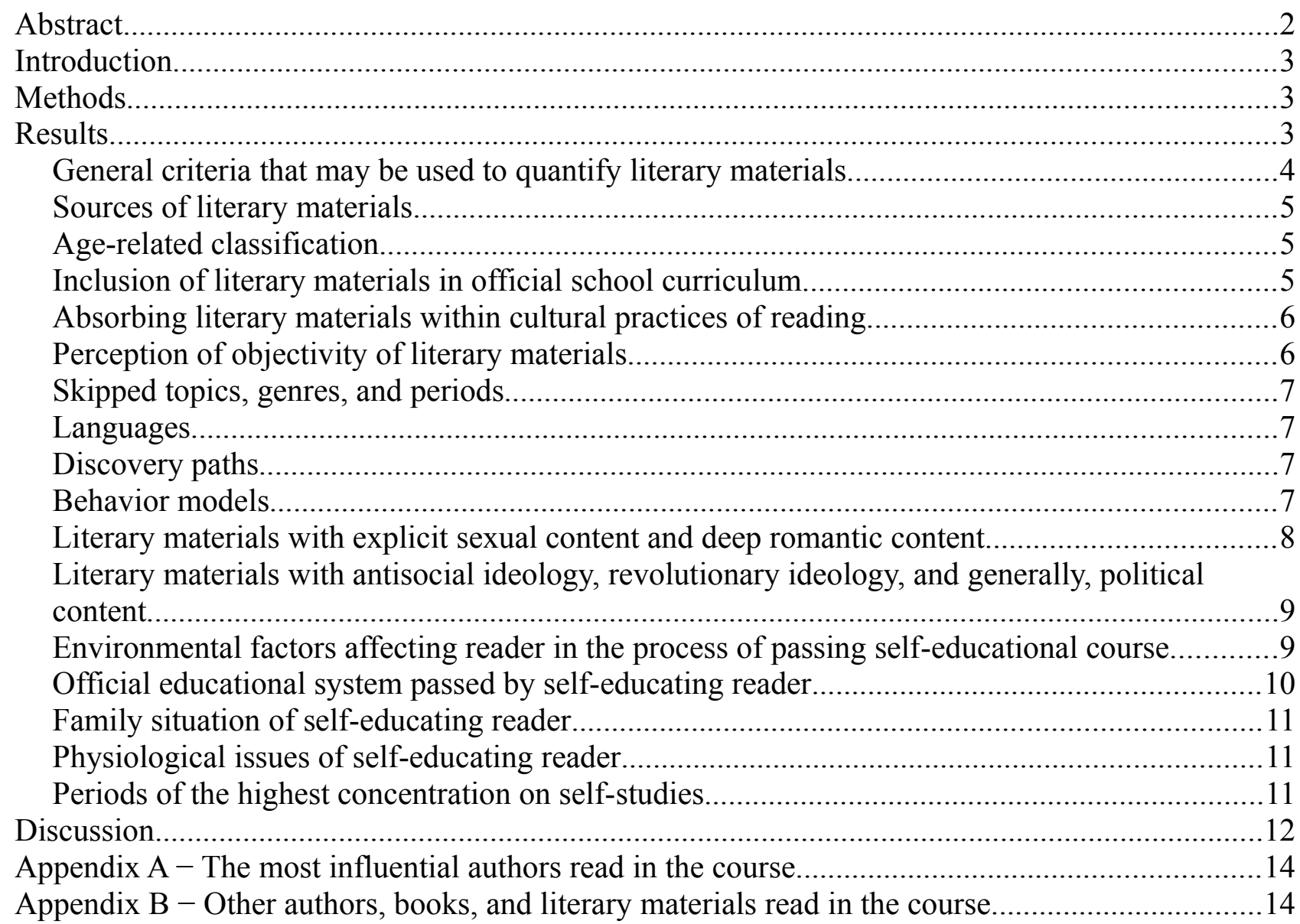




\begin{abstract}
Autoethnographic study for building methodology of researching teenage literary self-educational courses upon analysis of one such course consisting of about 200 authors and titles. In the process of study, the following has been discovered.

Ideas:

a) it may be worth to explore whether right of every child and teenager for self-education which is not controlled by any authorities, governments, and business entities could be included into Universal Declaration of Human Rights and Convention of the Rights of the Child.
\end{abstract}

Facts:

a) active literary self-learning is possible even in the situation of social collapse and criminalized society; such factors as support of relatives/teachers, intellectual/behavioral segregation within school, and density of libraries within pedestrian accessibility may overpower social trends; however, presence of large home library and accessible public libraries is not enough to stimulate teenagers to read much;

b) topics, styles, and rhythm of literary self-studies may change abruptly upon the end of teenage years;

c) even in educated family where active reading is encouraged by parents/grandparents some cultural practices of reading are not transmitted between generations;

d) some self-learners invent their own cultural practices of reading; and some of these practices may be very rare;

e) avid readers may skip significant portions of easily available literary materials and concentrate at others;

f) reading literary materials describing different sexual deviations may be completely unrelated to practiced sexual behavior as in teenage years as in adult years;

g) correlation between village-style thinking practiced by parents and self-learning practices of child may be non-linear;

h) periods of the highest concentration on self-studies spanned over many years may be not numerous and take 1-3 months each.

Hypotheses:

a) discovery paths of literary materials for reading could change significantly during the latest 20 years upon widespread usage of Internet and mobile devices;

b) correlation between nutrition quality and amount of self-learning may be non-linear. 


\section{Introduction}

In according to my personal opinion which probably may be easily supported by references to other researchers, literary self-educational course passed in teenage years may be one of the greatest boosters affecting all subsequent adult life of each particular person for the period of several tens years, and as a result of this, affecting global social life too. That's why such courses passed by different people independently in different parts of the world require maximum attention of professional researchers.

When I was teenager, I have passed such self-educational course unconsciously (although probably, not unconsciously for my parents, grandparents, teachers, and librarians). It included about 200 authors and titles. Summary of this course has been written down just when I was $40+$ years old. And after doing this, I came to the idea that all read materials can be easily classified into multiple categories intersecting with each other; so, it is possible to quantify multiple effects of the course just by quantifying amount of materials in each category. In this article, I would like to propose classification that may be reused by other researchers for exploring literary self-educational courses passed by teenagers and measuring effect of these courses on different aspects of personal and social life of readers after reaching adult age. Also, I'm explaining environmental factors and factual functioning of official educational system that can affect passing of such courses significantly, and may be easily manipulated by society to regulate amount of highly skilled professionals, and generally, amount of educated freely thinking people. Some details of personal life and family situation are given too where they are needed to understand the process of selflearning deeper.

Some dimensions of proposed classification are based on ideas for social researches published at https://doi.org/10.5281/zenodo.3364008 in 2019-2020 $0^{\text {th }}$ years.

To understand historical context of the passed course, it should be noted that I was born in $1978^{\text {th }}$ year, and first access to Internet was made after getting 18 years old only.

\section{Methods}

All published results have been collected after analysis of compiled list of literary materials just by recalling them in memory during many months.

Many authors listed in appendixes were published in "World Literature Library" book series ( “Библиотека Всемирной Литературы”") which is well-known in Russia; so, I used online catalog of this series to recall some of listed items. (I had at home the very first edition of this series.) To recall some titles/authors other public online catalogs were used.

Literary review of the topic has not been performed yet; I'm not a professional researcher, and I have limited access to academic materials. Maybe, in the future editions of this article, more theoretical background will be added. 


\section{Results}

Literary materials read in the course since getting 11 years old until getting 18 years old and used for building the proposed classification are listed in Appendix A and Appendix B at the end of this document. Only limited classification is applied in appendixes to minimize time expenses and to demonstrate how raw data obtained from respondents may look.

\section{General criteria that may be used to quantify literary materials}

- General library classification by genre, style, topic, epoch, and targeted modern age group. I guess, professional librarians may add more criteria.

- Whether particular literary material or author was influential and impressive for reader at the moment of reading or not.

- Whether particular literary material or author affected subsequent adult life directly (in according to opinion of reader after reaching adult age).

- Whether literary material has been read completely, or just started to be read. Several items listed in appendixes were not completed (about 5).

- Whether fact of reading literary material is under question even for reader, because it is hard to recall it in memory. Several items listed in appendixes fit in this category (less than 5).

- Whether large amount of works of particular author (more than 5 works, for example) has been read. About 10-15 authors listed in appendixes fit in this category. Probably, few of them whose works were read in extremely large amount (several tens volumes) may be extracted into separate category (about 5 authors in the lists fit in this category).

- Whether some particular literary works or authors were actively searched or were found just by chance.

- Distribution of read literature by sub-courses. I suppose, materials listed in appendixes may be classified into 10-20 sub-courses.

- Emotional impression taken from literary material or author. The most part of listed materials has given only positive or neutral emotions, but several authors/books (less than 5) have left very negative and/or depressive emotional impression.

- Whether illustrations/photos were significant motivational factor for reading particular author and/or literary material.

- Whether literary works were read multiple times. In my case, significant part of materials were re-read 2-5 times. Even many of those that are listed in Appendix B.

- Whether some literary materials listed as single item represent several books in fact (less than 5 in my case) and whether some literary materials listed separately were read in single book with collection of works (less than 5 in my case). I'm not sure how these data may be 
useful for you, but sometimes, it is simpler to list literary materials in such way due to personal preferences.

- Whether read materials were discussed actively with relatives, friends, and teachers.

\section{Sources of literary materials}

In my case, sources were purchases made by father, by mother, and by myself (for money given by parents), magazine subscriptions made by both parents together, literary materials taken by me from 4 regularly visited public libraries (school library, district library, central city library, and university library), literary materials taken by me from 2 public libraries in recreational villages (it is informal translation of Russian terms база отдыха, дом отдыха, санаторий) visited with parents at summers, and literary materials found in Internet (Internet access became available just when my teenage years have ended). The most part of books purchased by parents was purchased before my birth. As you can guess, tastes and interests of parents may differ, and by purchasing different materials for child, they train different parts of her/his mind, which may have long-lasting effect. It is supposed that such sources as other relatives, friends, classmates, and teachers may be considered too, although in my case they were absent.

It should be noted that presence of large home library and accessible public libraries is not enough to push child into the process of active reading, as I can see by my siblings. It is supposed that in addition to having large home library, the child should have some unsatisfied necessities of so-called "moderate intensity", both material and emotional that can be compensated partially through reading. It is supposed that if unsatisfied necessities are too large and serious, or vice versa, too small, then active reading cannot be used as substitution of desired objects and emotions.

\section{Age-related classification}

Reading of several of the listed authors (about 5-10) has been started much earlier than 11 years old (one was started at 7 years old), and few works (about 5) were read (however, mainly, without being completed) in the period since getting 18 years old till 30 years old. But I suppose, these authors and works must be considered as parts of teenage course too, because authors that were started earlier than 11 years old were read until getting about 15 years old, and works read after getting 18 years old were read by inertia. So, we may add the following temporal classification of read materials specifying when each particular author/work was read: pre-teenage years (before 11), early teenage years (11-13), mid-teenage years (14-16), late teenage years (17-18), post-teenage years (after 18 and up to 30, in case if reader feels that materials were read by inertia and they are not numerous).

\section{Inclusion of literary materials in official school curriculum}

It is obvious, that in spite of including some material or author in official school curriculum, real process of reading may happen outside of school. Also, it should be noted that in Russian high schools of 1980's and 1990's, the accent in studies was made at learning/teaching mathematics and natural sciences, humanities were taught in a perfunctory manner, sports was considered as optional 
subject de facto; cheating at exams was considered as widespread norm; those students who did not want to read large fiction materials included into official literary curriculum could purchase easily in street book shops the collections of outlines of all novels taking just several pages each, and even ready essays that could be submitted at exams. That's why in my case, it is reasonable to consider official school literary curriculum as the part of self-studies.

\section{Absorbing literary materials within cultural practices of reading}

My father told me that when he was a kid, he read aloud large books for his mother and aunt at evenings (one Jules Verne's novel was mentioned by him). They lived in a tiny provincial conservative town, Nukus in Uzbekistan, where few ways to spend free time could be available. I don't know who came to idea of doing this - he, his mother or aunt (both were working class women), or it was recommendation of school teachers - but I guess, if this cultural practice has been used in family, then authors/works read in such way may be classified in a separate group. In my case, such practice was completely absent. However, I invented by myself two other cultural practices of reading. The first was reading books at school lessons (unrelated school lessons, for example, Shakespeare's works at geometry lessons). I consider it as cultural practice, because I have found later in Internet that many people did it in Russia (although in my class I was the only one). The most part of teachers in Russian schools of that historical period did not care much about such reading practice, especially if student had top grades in taught subject. The second practice was reading books at dinner at home, with eating simultaneously. I have seen this practice used by another person only once in my life, when I met one young French lady in my travel to Madagascar.

I'm not sure whether regular re-reading of the same books during many years may be considered as cultural practice, but as I wrote above, significant portion of literary materials listed in appendixes was re-read multiple times.

\section{Perception of objectivity of literary materials}

Due to economical, geographical, and family circumstances, my teenage and youth explorations of social and natural worlds biased towards obtaining information from fiction literature and art works; round-the-world travels have been started in adult age only, when I had already extensive background in studies of all kinds of literature and arts (it should be noted that I was semi-professional creative writer by this time). As a result of this situation, my travels, and generally, my life were directed to exploring the world outside of content of literary and art works. After summarizing all this experience, I can say that in my personal opinion no more than $10 \%-20 \%$ of the world can be known from fiction literature and art works, no more than $30 \%-40 \%$ can be known from popular science books, travel blogs and mass news articles in magazines or Internet, and no more than $30 \%-40 \%$ can be known from scientific monographs and publications. Every of these sources either skips or distorts significant portions of reality. Or just goes several years (or more) behind the reality. Obviously, this observation is very subjective. But it gives us one more dimension for quantifying literary materials passed in self-educational courses: what is personal opinion of teenage reader on how objective are the read literary materials in relation to the modern world surrounding her/him? 


\section{Skipped topics, genres, and periods}

The most part ("the most" considering repeated reading) of "serious" fiction literary materials listed in appendixes that I have explored outside of school program either has been written more than 100 years ago (even by the time of reading) or contains information about societies from more ancient periods of history. Why I avoided reading more modern authors and reading materials about more recent periods of history? Just because the history of the whole $20^{\text {th }}$ century looked for me like crazy jumps performed by human civilization from one side to another. That's why I did not feel strong connection between characters and ideas expressed in the literature of $20^{\text {th }}$ century and modern reality. In contrast to this, all literature written prior to $20^{\text {th }}$ century looked as sequential development of ideas for several thousands years. In other words, I did not feel practical necessity to read the most part of literature written in $20^{\text {th }}$ century. I'm not sure whether it is my personal particularity (caused by growing up in 1990's in the middle of Russia) or common trend. However, it gives us two more dimensions for classifying literary materials: does reader skip some historical periods, genres, or topics with a purpose? does reader skip some historical periods, genres, or topics due to difficulties in understanding?

\section{Languages}

About $99 \%$ of materials listed in appendixes have been read by me in Russian language, remaining part was read in Tatar language. It includes all ancient novels, dramas, and epic literature from multiple countries that may sound very archaic for native speakers of languages used by authors of these works. For me, all this looked like historical works written by modern Russian-speaking authors. Definitely, it changed my attitude to these literary materials significantly, simplified reading, and allowed deeper immersion in text. So, classification on the basis of languages of texts and archaism levels of these languages may be also applicable.

\section{Discovery paths}

It may be good idea to introduce into research such concept as discovery path. In my case, it was almost absent, the search of literature has been performed just physically in home library, in other libraries, and in paper catalogs of other libraries. But in the modern world, presence of multiple Internet resources and widespread usage of mobile devices may allow teenage readers to construct in their heads very long and complex discovery paths in the process of searching literature. So, the materials found by very long and complex discovery paths may be classified into separate group.

\section{Behavior models}

Some teenage readers could use authors and characters from the read literary materials as behavior models. In my case, such phenomenon was present too (about 30 models of 11 types were taken) but on sub-conscious level only and partially only, because I'm too reasonable person and the most part of read materials was too old/outdated even by 1980's and 1990's. The following types of models were taken from the read literary materials: 
writer, boy exploring the world, explorer of wild nature, wanderer, wildman, young man exploring the world, artist, antisocial person, thinker, ecologist, entrepreneur.

\section{Literary materials with explicit sexual content and deep romantic content}

You may see in appendixes that some read materials like "Encyclopedia of World Arts History", "Ethnographic Encyclopedia", and works of Apuleius, Giovanni Boccaccio, Giacomo Casanova, Marquis de Sade, Pablo Neruda, Irvine Welsh contain a lot of sexological, erotic, or pornographic stuff. That's why classification on the basis of presence of explicit sexual content may be also needed.

Besides materials with explicit sexual content, there may be literary works that highlight emotional parts of sexual life deeply, and in some conservative families living far from large cities, such literary works may be the only or main source of information on this topic for kids, and that's why they may be classified separately. The latter idea is based on occasional communication with my mother about Gustave Flaubert's works (she grew up in Bishkek, Kyrgyzstan); however, I did not read this author by myself and did not communicate with my mother much about this.

Also, I guess that some teenage readers may use authors and characters from the read literary materials as sex symbols; in my case, such phenomenon was almost absent; the only sex symbols that I have obtained from literature are general types of female exploring wild nature (without concentrating at images/names of particular personalities) and exotic female warrior. But I never used these symbols in sexual fantasies, they were purely psychological sex symbols.

It should be explained that sexual and romantic templates found in literature did not affect my personal life at all. The same may be said about templates of sexual and romantic life of ordinary people living around me, both relatives and non-relatives, they did not affect me at all too. Due to particularities of my personality, I always followed only my internal feeling of what is "reasonable", what is "good", and what is "romantic" in relationships with females, even if it placed me into dangerous or ridiculous situations. Short summary of my personal life is given further to illustrate the statements above:

a) my first romantic feelings were towards female classmate with dark skin and high level of intellect; it was just child romantic interest, although later, in adult age, I used her intellectual, psychological, and visual types as "average" in the process of searching females for marriage;

b) as a result of severe conflict between me and my parents about choosing life paths, I did not practice sexual relationships until getting 26 years old;

c) since 26 years old till getting 40 years old I searched actively females of my age (plus/minus 3-8 years) for romantic monogamous semi-matriarchal semi-individualistic marriage; however, nobody suitable was found (you should understand that my life interests, income, places of living, and circles of communication varied significantly during those 14 years); 
d) in the same period of time, I entered in one-night stand relationships with several females who were significantly older than I was, 10-20 years older; just to avoid accidental pregnancy and to avoid getting infected with STDs from one-night stands with females of lower social circles; very strict filtering by psychological types was performed, for some of these ladies I was the second partner in their lives or, probably, the first younger partner;

e) after getting 40 years old and being very tired of resultless searches, I entered approximately the same number of one-night stand relationships with females who were significantly younger than I was, 12-20 years younger; but all of them were from lower social classes, expected to be paid for relationships, and were not satisfactory for the role of wife/mother.

I doubt that you will be able to find any similar template of sexual behavior in fiction or autobiographic literature. So, speaking shortly, the fact that teenager reads actively the literature describing multiple sexual deviations or literature that emphasizes romantic part of relationships does not mean that templates from this literature will be really practiced in daily life in adult age, other factors may outweigh them.

\section{Literary materials with antisocial ideology, revolutionary ideology, and generally, political content}

Considering that in "Discussion" section of this article I touch political questions, it is reasonable to understand what part of self-educational courses passed by teenage readers contain materials that promote antisocial behavior (in 1990's meaning of the word antisocial), revolutionary ideology, and political thinking. In my case, there were just about 10 such books in the whole course. However, if meaning of the word antisocial will be extended to cover all kinds of adventurous and analytical behavior, then, probably, the most part of literature listed in appendixes may be classified as promoting antisocial behavior; although, you should understand that in 1980's and 1990's such classification would look very strange or ridiculous for everybody.

\section{Environmental factors affecting reader in the process of passing self-educational course}

For better understanding the process of reading large amounts of literary materials you may consider climatic and social environments which may affect reading habits significantly.

In my teenage years, I lived in Kazan city in Russia where climate is rather harsh, about one third of year staying outdoors is difficult because of heavy rains or severe frosts, and my relatives were not hikers at all. In 1980's, teenage crime flourished in the city, each district was controlled by some gang, and violent clashes happened regularly. In 1990's the situation calmed down gradually, but general social environment was still hostile, and nobody was surprised that kid like me prefers to stay almost all time at home or in libraries. To illustrate hostility of environment even in the mid of 1990's, I can provide one simple example: I lived with parents in a typical giant house with multiple apartments, the house was located in rather good neighborhood by standards of those times, when significant part of Kazan population lived in favela-style wooden barracks; but periodically, at late 
night, in public areas of the house in several steps from my apartment door, it was possible to meet drug consumers performing injections, used syringes could be found in dark corners at morning.

Global sexual revolution has reached the city in 1990's, it happened simultaneously with the peak of informational TV propaganda about risks of getting HIV; this situation together with somewhat conservative attitudes of my parents explains why I preferred to sublimate my sexual impulses into literary self-learning instead of experimenting with neighbor ladies.

\section{Official educational system passed by self-educating reader}

Also, maximum attention should be paid to educational system the teenage reader is passing through in the process of self-studies.

In Russia of 1980's and 1990's, 10-year educational program was used, kids started schooling after getting 7 years old and graduated after getting 16 years old. Then, the most part of graduates continued studies in local technical universities with rather weak admission criteria (and continued to co-habit with parents during studies).

Usage of electronic devices in the process of studies was almost absent outside of the largest cities.

Starting from about getting 10 years old, the students were actively regrouped by teachers between school classes in according to their intellectual abilities, behavior, and financial opportunities of parents. (You should understand that schools were underfinanced at those times and the whole school system was corrupted heavily through so-called financial assistance that was gathered from parents regularly.) As a result of such segregation of students, you could find in every ordinary school rather strict differences between school classes in spite of the fact that all students lived in the same neighborhood; some classes could be composed almost completely of teenage gangsters and kids with underdeveloped intellectual abilities, and in parallel classes you could find students like me who put a lot of efforts into studies and self-studies. However, it is necessary to highlight again the fact that segregation was not intellectual, it was also behavioral and financial; so, speaking shortly, you could be beaten in any class. If such approach to segregating teenagers (including those who were members of gangs) looks strange for you, you should understand that I lived in Central Asian part of Russia (in Tatarstan), where authority of teachers, and generally, authority of the state officials was respected by all parts of the society; it explains why segregation was followed in some or another way even at breaks between lessons. I'm not sure how it worked and whether it was practiced in other parts of Russia having mainly Slavic population. However, probably, creation of comfortable environment for studies and self-studies even in standard schools with teenage gangs was widespread educational approach in Russia of that historical period as a result of Cold War when many cheap professionals were needed; but it is just my guess, I did not explore this topic in literature.

\section{Family situation of self-educating reader}

My parents and grandparents had a lot of problems: social, medical, age-related, psychological, financial etc. Without digging in their lives too deeply I can summarize that main consequence of 
these problems that affected my self-studies consisted of lack of my parents' socialization on interpersonal level, their prejudices against different ethnocultural groups, and village-style thinking that caused underestimation of kids' abilities with some rigidity in accepting changes of life style. All this together blocked my professional self-development (although I started thinking about it since about 15 years old very seriously) and redirected my energy to reading, watching TV/movies, and sports primarily. Blocking occurred as through direct conflict with parents as through unconscious imitation of their behavior by myself.

\section{Physiological issues of self-educating reader}

I think, it is obvious that person who needs to spend much time at home due to health issues will read more often. It should be considered by you in the process of researching other respondents. But in my case the problem was completely different: due to economic situation of 1990's in Russia and due to lack of my parents' knowledge in healthy nutrition I did not consume enough protein, microelements, and fiber when I was teenager (especially such food as fruits, nuts, and fish); later, after starting living alone, I began to consume 2-4 times more such food than in the times when I lived with parents. I suppose, it was the main reason of so lengthy teenage development (since 11 till 18 years old), and as side effect, so lengthy literary self-learning chosen by me as the most productive activity which requires minimal input of energy. In case if I would have better nutrition, I would probably become psychologically adult by getting 16 years old, would probably try to start sexual life much earlier, and would probably complete literary self-studies at the same time.

\section{Periods of the highest concentration on self-studies}

I hardly recall these details in memory, but, probably, they may be one of the most important part of researching self-educational courses stretched over several years. As I remember, there were periods of the highest concentration on reading: probably, 1-2 of them were at summers when no school studies were performed, and probably, 2-3 were at winters (since November till April); each of periods took 1-3 months. Active reading was performed in other parts of the year too, but it could be done by inertia. These data should not be considered as reliable. However, you may consider as reliable the statements that such periods were not numerous, and that such periods could take 1-3 months each (not weeks and not years). Probably, these periods may be considered as the most important for absorbing explored materials and the most vulnerable for external pressure. So, if your kid is deeply immersed in self-studies, you should track these periods somehow to be able to protect her/him from the society and accidents.

To dig in this topic deeper, it may be interesting to collect data on the total number of periods of the highest concentration during teenage years. The results may be quite surprising: in my case, as I can recall in memory, the total number of periods of the highest concentration on watching movies, watching music videos, watching TV programs, school studies, communication with relatives and classmates, sports, and thinking was about several tens. So, it may be stated that in spite of taking just minor part of periods of the highest concentration the literary self-studies may influence teenage mind rather deeply. 


\section{Discussion}

It is supposed that provided approach to quantification of literary self-educational courses may help pedagogues, child/teenage psychologists, and parents to implement better strategies for educating children and pushing social progress.

At the same time, it is obvious that deep understanding of neurophysiological and social effects of teenage self-educational courses (discovered after researching several hundreds of such courses, like mine) may allow totalitarian, criminalized, and manipulative governments and particular representatives of authorities to press down societies and individuals to keep existing hostile social order. (I'm not talking about Russia; due to geopolitical situation of Russia, educational system is very specific there, and in the times when I was teenager self-education was encouraged, as I wrote above.) It is supposed that simple psychological interventions performed through official educational system may decrease effect of self-educational literary courses easily. That's why in deeper research of this topic, it is recommended to find solutions to counteract such interventions on family level and on personal level. Basing on my personal experience described above and on information from public news, it is possible to guess several educational practices that may be very harmful to deep immersion in text which is required to pass really large and serious courses:

- active usage of tablets in the process of learning (in addition to altering reading practices, it gives too high stress to eyes);

- recomposition of students between classes in such way to eliminate opportunities for and necessity in intellectual leadership; for example, to include in every class several members of teenage gangs or physically developed teenagers having low grades;

- using school psychologists to discover kids who are in the periods of deep psychological concentration on self-studies and "break" them with some medications.

I'm not sure about current trends in government control over self-education of teenagers in different countries around the world, this topic requires active review of literature and interviewing people from multiple locations. (You should understand that laws, regulations, traditions, practical application of all this to daily life, and daily life by itself may vary and even contradict each other significantly between regions and social strata of every particular country.) But if such trends really exist and grow, it is worth to explore whether right of every child and teenager for self-education which is not controlled by any authorities, governments, and business entities could be included into Universal Declaration of Human Rights and Convention of the Rights of the Child. Because this right may be crucial for social progress in the modern aging society.

To illustrate probable importance of such addition to these fundamental documents and to explain how quickly the world is changing, I would just give you several possibly unrelated news that I have read in public sources during summer of $2021^{\text {st }}$ year:

- in one of schools in Moscow in Russia, a pilot video surveillance program has been started that performs face recognition of students and tracks their behavior to detect changes that 
last for more than three consecutive days and too active movements, like running through school halls;

- in UN report on war conflict in Lybia there was information about military robot that attacked retreating local fighters independently, without getting instructions from remote operator;

- China cracked down on education industry.

However, for being objective and to avoid giving only positive flare to teenage self-education, it should be noted that in the future world where aged population may exceed any reasonable amounts, self-educated young population not controlled by anybody may accidentally come to the idea of genocide for minimizing costs of supporting aged part of population. It is just an example of hypothetical nightmare situations that you should consider in your research of teenage self-education control.

(Please, check appendixes with literary materials used for this research on the following 2 pages.) 
The term medieval used further includes the period since $5^{\text {th }}$ up to $18^{\text {th }}$ century AD. The term ancient includes the period before $5^{\text {th }}$ century AD. Square brackets mean forgotten title and/or author.

\section{Appendix A - The most influential authors read in the course}

\section{Classic Literature}

Alexandre Dumas

Anton Chekhov

Arthur Conan Doyle

Charles Dickens

Edgar Allan Poe

Emily Dickinson

Ernest Hemingway

Henryk Sienkiewicz

Herman Melville

Honoré de Balzac

Irving Stone

Jack London

Jules Verne

Mario Puzo

Mark Twain

Pablo Neruda

Rafael Sabatini

Stendhal

Thomas Mayne Reid

Walt Whitman

Washington Irving
Science and Popular Science

Bernhard Grzimek

Dinah Moché

Gerald Durrell

Jane Goodall

Joy Adamson

Thor Heyerdahl

\section{Ancient and Medieval}

World Literature

Arabic fairy tales

Chinese medieval stories

Ferdowsi (Shahnameh)

French medieval playwrights

Indian epic stories

Japanese medieval poetry

Korean medieval stories

Scandinavian epic stories

Spanish medieval playwrights

William Shakespeare
Science Fiction

Andre Norton

Clifford D. Simak

Harry Harrison

Ivan Efremov

J.-H. Rosny aîné

Paul Anderson

Vladimir Obruchev

\section{Appendix B - Other authors, books, and literary materials read in the course}

\section{Classic Literature}

Agatha Christie

Anne et Serge Golon

Alphonse Daudet

Antoine de Saint-Exupéry

Arkady Gaidar

Émile Zola

Erle Stanley Gardner

Ethel Lilian Voynich

[French poetry of $19^{\text {th }}$ century]

Friedrich Schiller

George Bernard Shaw

George Gordon Byron

George Sand

Gottfried Keller

Guy de Maupassant

Heinrich Heine

Henrik Ibsen

Irvine Welsh
Ancient and Medieval World Literature

African fairy tales

Ancient Greek dramas

Ancient Greek mythology

Apuleius

Arabic medieval poetry

Beowulf

Blaise Pascal

Central Asian parables

Chinese medieval poetry

Daniel Defoe

Dante Alighieri

Denis Diderot

European medieval poetry

European medieval stories

François de La Rochefoucauld

François Rabelais

Geoffrey Chaucer
Science and Popular Science

[About 5 monthly magazines with popular science and world news]

[Advertisement in Western economics]

[Analysis of Quran]

[Autobiography of one French

speleologist]

[Biography of Alexander the Great

(of Macedon)]

[Biography of Benvenuto Cellini]

[Biography of Marie Antoinette]

[Biography of Nicholas

Miklouho-Maclay]

Carlos Castaneda

Christopher Columbus' diaries

[Conspiracy trash]

[Cryptozoological trash]

David Livingstone's diaries 
James Fenimore Cooper

Jaroslav Hašek

Jean-Paul Sartre

Johann Wolfgang von Goethe

Karel Čapek

Milan Kundera

O. Henry

Orson Welles

Prosper Mérimée

Raffaello Giovagnoli

Reginald Rose

Robert Louis Stevenson

Stefan Zweig

Theodore Dreiser

Thomas Hardy

[Wildlife fiction stories about

Canadian North]

Wilkie Collins

William Somerset Maugham

\section{Russian/Soviet Literature (passed in school studies)}

Alexander Fadeyev

Alexander Griboyedov

Alexander Ostrovsky

Alexander Pushkin

Aleksandr Blok

Aleksandr Solzhenitsyn

Aleksey Tolstoy

Ancient Russian epos

Anna Akhmatova

Boris Pasternak

Boris Polevoy

Fyodor Dostoyevsky

Fyodor Tyutchev

Gabdulla Tuqay

Ilya Ilf and Yevgeny Petrov

Ivan Bunin

Ivan Goncharov

Ivan Turgenev

Konstantin Paustovsky

\section{Science Fiction}

Aldous Huxley

Alexander Belyaev

Arthur C. Clarke

[Collection of stories from US

science fiction writers]

Daniel Keyes

Herbert George Wells

Isaac Asimov
Giacomo Casanova

Giovanni Boccaccio

Irish epic stories

Irish fairy tales

John Milton

Jonathan Swift

Henry Fielding

Legends of Crimean Tatars

Marquis de Sade

Miguel de Cervantes

Persian medieval poetry

Pierre Choderlos de Laclos

Robert Burns

Stories about Hodja Nasreddin

The Song of the Nibelungs

Vietnamese medieval stories

Voltaire

Konstantin Simonov

Leo Tolstoy

Maxim Gorky

Mikhail Bulgakov

Mikhail Lermontov

Mikhail Prishvin

Mikhail Saltykov-Shchedrin

Nikolai Gogol

Nikolai Leskov

Nikolai Ostrovsky

Nikolay Chernyshevsky

Nikolay Nekrasov

Poets of the Silver Age (those who are not listed here)

Sergei Yesenin

Tatar classic prose and poetry

Venedikt Yerofeyev

Vladimir Korolenko

Vladimir Mayakovsky

John Wyndham

Kir Bulychev

[One book of some French

science fiction writer]

Ray Bradbury

Robert A. Heinlein

Roger Zelazny

Stanisław Lem
[Ecology and Wildlife Protection]

"Encyclopedia of World Arts

History"

[Entertaining Linguistics]

[Entertaining Mathematical

Problems]

"Ethnographic Encyclopedia"

[Ethnomedical notes from Yemen

by Russian military doctor, $20^{\text {th }}$

century]

"General Encyclopedia"

[Geology and History of Famous

Gems]

[Guide on breeding parrots]

[History of Anthropology: two

different books]

[History of Arts of Roman Empire]

[History of German Nazism]

[History of Impressionism]

[History of Islam]

[History of Wild West]

[Latin/Roman Aphorisms]

[Political System of the USA]

[Short guides in wushu, karate, bodybuilding, and taijiquan]

[Travel notes from from Tierra del

Fuego, $20^{\text {th }}$ century]

[Travel notes from Inuit villages in

Greenland, $20^{\text {th }}$ century]

[Tutorials of Arabic language]

[Tutorials of about 8 other foreign languages]

[Yoga guides and history]

"Zoological Encyclopedia" 